\title{
DISASTROUS ICE BREAKS IN EASTERN SERBIA - GIS ANALYSIS OF THEIR RELATIONSHIP WITH OROGRAPHIC CHARACTERISTICS
}

\author{
Nenad MARKOVIĆ ${ }^{1}$, Miroslava MARKOVIĆ ${ }^{2}$
}

\begin{abstract}
At the end of November/beginning of December 2014, an ice wave hit the whole of eastern Serbia and caused extensive ice and snow breaks in the forest areas managed by SE 'Srbijašume` - Forest Estates of Niš, Boljevac, Kruševac, Despotovac and Kučevo. The areas affected were determined by identifying all the affected units of forest division - with the lowest accuracy at the level of forest stands and, where possible by GPS recording in the field in order to ensure greater accuracy. The identified areas were presented in GIS mapping software. The total area affected by ice breaks amounted to 19,419.78 ha. It included 8,301.01 ha of high forests, 8,997.37 ha of coppice forests and 2,121.40 ha of artificially-established stands. Considering the size of the forest area affected by ice breaks on the one hand, and the huge environmental impact of forests on the other hand, this phenomenon may be considered a natural disaster. Having identified the affected forest areas, an analysis of the relationship between orographic characteristics and ice break occurrence was carried out with the use of GIS tools. The following orographic characteristics were studied: the elevation, the terrain aspect and the slope, all obtained from the digital elevation model (DEM) at a resolution of 1 arc-second. Elevation had the greatest influence on the occurrence of ice breaks. The largest area affected (ca.17,000 ha) was in the range from 600 to $900 \mathrm{~m}$ above sea level, i.e. in the belt of lowmountain relief. Regarding the aspect of the investigated terrain, the largest areas affected

\footnotetext{
1 Autor za kontakt: Nenad Marković, B.Sc., SE`Srbijašume`, Bulevar Mihaila Pupina 113, 11000 Belgrade, tel. +381648155041, Email: marnen67@gmail.com

2 Dr Miroslava Marković, naučni saradnik, Institut za šumarstvo, Beograd
}

Acknowledgment: The study was carried out within the Project TR 31070 "The development of technological procedures in forestry with a view to an optimum forest realization”, financed by the Ministry of Education, Science and Technological Development of the Republic of Serbia (2010-2019).
\end{abstract}


by ice breaks had northern (ca. 4,000 ha) and northeastern aspects (ca. 3,500 ha), while the remaining areas were equally distributed in all other aspects. The slope was not found to have any significant effects on the occurrence of ice breaks. This disaster brought about most severe and extensive consequences in broad-leaved and coniferous ecosystems and the environment in general, with long-term adverse effects such as changing soil water regimes, erosion, declining atmospheric oxygen levels and reduced carbon accumulated in biomass.

Keywords: ice breaks, GIS, elevation, aspect, slope, environment

\title{
КАТАСТРОФАЛНИ ЛЕДОЛОМИ У ИСТОЧНОЈ СРБИЈИ - ГИС АНАЛИЗА УСЛОВЉЕНОСТИ ОРОГРАФСКИМ КАРАТЕРИСТИКАМА
}

\begin{abstract}
Извод: Крајем новембра и почетком децембра 2014. године, ледени талас који је захватио иелу источну Србију проузроковао је појаву великих ледолома, ледоизвала и снеголома на површинама којима газдује ЈП „Србијашуме“, односно на подручју иумских газдинстава Ниш, Бољевач, Крушевац, Деспотовац, и Кучево. Утврђиваье површина захваћених ледоломима и ледоизвалама извршено је дефинисањем свих захваћених јединица просторне поделе шума, најмағе тачности на нивоу одсека, а где је то било могуће и прецизније снимањем уз помоћ ГПС апарата. Те повриине су картиране у ГИС технологији. Укупна површина државних шума захваћених ледоломима је 19.419,78 ha, од чега на високе шуме отпада 8.301,01 ha, изданачке 8.997,37 ha и вештачки подигнуте састојине 2.121,40 ha. С обзиром на велику површину шума захваћену ледоломима, као и на њен огроман утицај на животну средину, ова природна непогода може се сматрати катастрофалном. После дефинисања површина захваћени ледоломима, ГИС алатима извршена је анализа условљености појаве ледолома орографским карактеристикама. Од орографских карактеристика анализирана је надморска висина, експозиција и нагиб терена. Детаљне орографксе каракеристике подручја захваћених ледоломима добијене су из дигиталног елевационог модела (DEM) прецизности 1 ARC-second. Највећи утииај на појаву ледолома имала је надморска висина. Највећа површина погођена ледоломима (око 17000 ha) налази се у појасу 600-900 м.н.в. тј у појасу нископланинског рељефа. Што се експозиције тиче, највеће повриине погођене ледоломима налазе се на северној (око 4000 ha) и североисточној експозицији (око 3500 ha), док је остатак површина равномерно распоређен по осталим експозицијама. Нагиб није показао значајан утуцај на појаву ледолома. Констатоване су озбиљне и тешке последице, које је природна непогода оставила на четинарски и лишћарски шумски екосистем и животну средину, као и дуготрајне последице: промена водног режима у землишту, интензивирање ерозије, смањење количине кисеоника, смањење количине угљеника акумулираног у биомаси.
\end{abstract}

Кључне речи: ледоломи, GIS, надморска висина, експозиција, нагиб, животна средина

\section{INTRODUCTION}

Freezing rain brought a lot of trouble to eastern Serbia at the end of 2014. The damage caused by ice breaks in the forests of Serbia in late November and 
early December was enormous. The ice wave hit the whole of eastern Serbia and made unforeseen damage in the area of forest estates of 'Južni Kučaj' Despotovac, 'Severni Kučaj' - Kučevo, 'Timočke šume' - Boljevac, 'Niš - Niš and 'Rasina' - Kruševac.

Freezing rain is a type of precipitation that starts as snow which melts on the way to the ground as it passes first through a layer of air with temperatures above zero, and then through a layer of cooler air. Raindrops become super-cooled while passing through a sub-freezing layer but they freeze only when they encounter a surface with a temperature below zero. This is exactly what happened in this case - when the raindrops fell on the trees, the ice that formed on the branches bent branches and trees and ultimately caused their breaking or even uprooting of entire trees (Pictures 1 and 2).

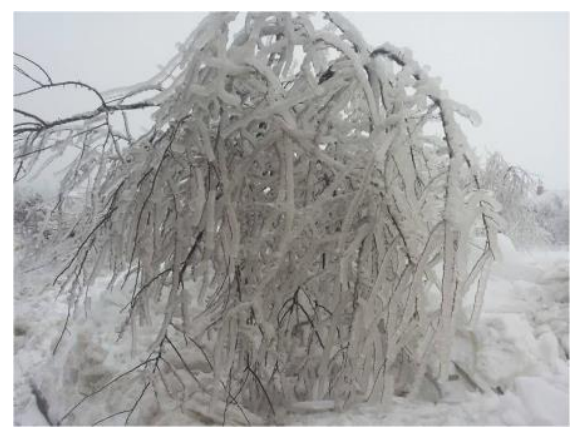

Picture 1. Consequences of freezing rain

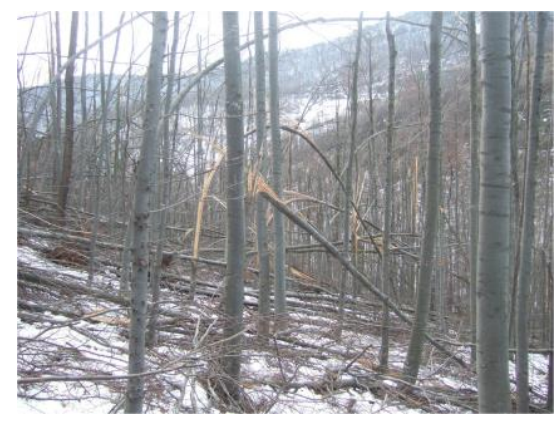

Picture 2. Consequences of freezing rain

This paper analyzes the effects of orographic factors on the occurrence of ice breaks and their impact on the environment.

\section{MATERIAL AND METHODS}

\subsection{Identification of the areas affected by ice breaks}

In such natural disasters, it is necessary to define the area and the intensity of damage as soon as possible. The areas affected by ice breaks were determined by identifying all the affected units of forest division - with the lowest accuracy at the level of forest stands and, where possible by GPS recording in the field in order to ensure greater accuracy. However, since ice breaks hit large areas of forest, it was enough to identify and map the affected area in the field within the sections that are registered in the geodatabase of the forest division into management units, compartments and forest stands. The identified areas were then mapped in GIS technology. The total area of state forests affected by ice breaks was 19,419.78 ha, where high forests account for 8,301.01 ha, coppice forests for 8.997,37 ha and artificially-established stands for 2,121.40 ha. Picture 3 shows the area affected by ice breaks. 


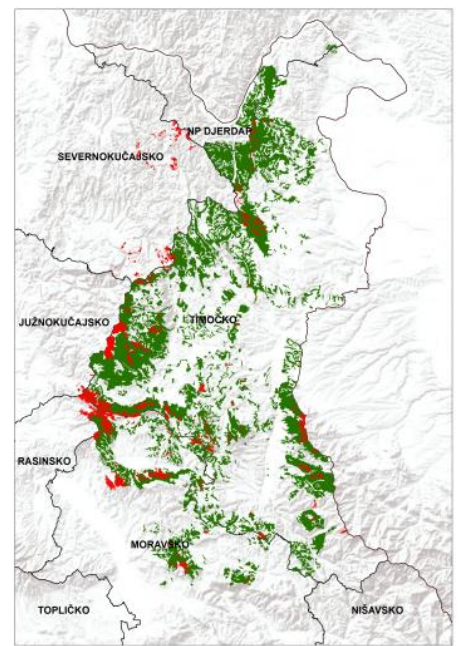

Picture 3. The area affected by ice breaks

Although the affected area of state forests is huge (red colored in the figure), the real scope of the disaster can only be seen if we include the damaged areas of privately-owned forests. The overall consequences cannot be determined only through the financial loss, i.e., their impact cannot be valorized solely through the main forest product - wood. The damage is much more significant, extensive and lasting if we take into account its ecological and biological aspects.

\subsection{Orographic characteristics of the affected areas}

The analyzed orographic characteristics included the elevation, the aspect and the slope of the terrain. Detailed orographic characteristics of the areas affected by ice breaks were obtained from the digital elevation model (DEM) at a resolution of 1 arc-second (Picture 4).

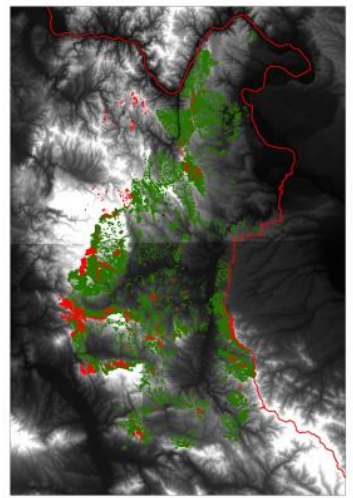

Picture 4. Detailed orographic characteristics of the areas affected by ice breaks

By processing the digital elevation model using GIS tools, we obtained the layers of elevation (Picture 5), aspect (Picture 6) and slope (Picture 7). 

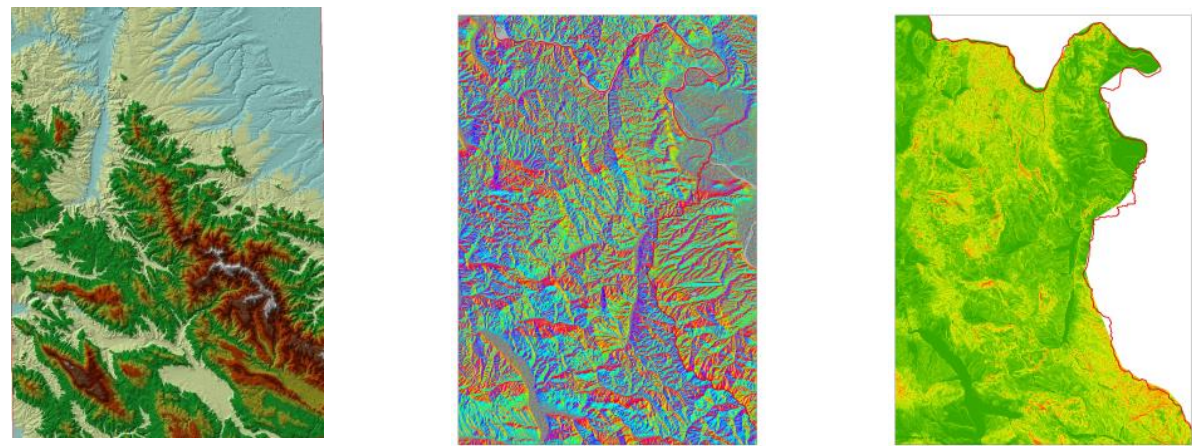

Picture 5, 6, 7 - The elevation layers derived from the digital elevation model

The digital elevation model was initially converted into the grids of elevation, aspect, and slope, but these grids were in the second step converted into vector layers to facilitate the subsequent analysis and intersection of these layers with the layer showing the damaged areas.

\section{RESULTS AND DISCUSSION}

\subsection{An analysis of the dependence of ice break occurrence on orographic characteristics}

The obtained layers of elevation, aspect and slope were first overlapped with the layer that shows the damaged surface areas and then they were intersected with this layer, thus providing new polygon layers which in the attribute table contained data from both layers that participated in the cross-section for each element-polygon. Thus, each element - polygon in the newly obtained layers is accompanied by the data on the type of damage, the area, as well as the elevation, aspect and slope.

This made it possible to determine the size of the damaged area at individual elevations, aspects and slopes.

Elevation had the greatest impact on the occurrence of ice breaks. The largest surface area affected by ice breaks (about $17000 \mathrm{ha}$ ) is located in the range from 600 to $900 \mathrm{~m}$ a.s.l., i.e., in the belt of low-mountain relief (Table 1).

Table 1. Area affected by ice breaks

\begin{tabular}{|l|r|}
\hline \multicolumn{1}{|c|}{ Relief/ } & Area (ha) \\
\hline Hilly & 1.676 \\
\hline Low-mountainous & 17.570 \\
\hline Medium-mountainous & 648 \\
\hline
\end{tabular}

Regarding the aspect, the largest areas affected by ice breaks have northern (about 4000 ha) and northeastern aspect (about 3500 ha). The remaining areas are 
equally distributed in all other aspects. The slope did not show any significant effects on the occurrence of ice breaks.

Table 2. Aspect of the areas affected by ice breaks

\begin{tabular}{|l|r|}
\hline \multicolumn{1}{|c|}{ Aspect } & \multicolumn{2}{|c|}{ Area (ha) } \\
\hline Northern & 4.013 \\
\hline Northeastern & 3.316 \\
\hline Southern & 2.619 \\
\hline Southwestern & 2.471 \\
\hline Northwestern & 2.129 \\
\hline Eastern & 1.836 \\
\hline Southeastern & 1.797 \\
\hline Western & 1.678 \\
\hline Flat & 4 \\
\hline
\end{tabular}

\subsection{Environmental impact}

Although the state forests suffered enormous damage - over 400,000cubic meters of wood, the overall consequences cannot be determined only through the financial loss, i.e., their impact cannot be valorized solely through the main forest product - wood. The damage is much more significant, extensive and lasting if we take into account its ecological and biological aspects. Forest habitats within the forest stand complexes that have suffered a higher intensity of damage are to be changed significantly.

Degradation processes which are yet to occur will cause the regressive succession of forest communities and the impoverishment of the soil that will be inhabited by those tree species that represent the initial stages in the ontogenetic development of the forest stand. All of the above point to the important role of habitat in the development of forests, but it is also interesting to see how the habitat itself can contribute to the occurrence and intensity of damage.

This natural disaster exerted severe and extensive effects on the coniferous and broadleaved forest ecosystem and the environment of the damaged areas and brought about other long-term effects, such as changes in the soil water regime, erosion, declining atmospheric oxygen levels and reduced carbon accumulated in biomass.

\section{CONCLUSIONS}

The largest area affected by ice breaks (about 17000 ha) is located in the belt between 600 and $900 \mathrm{~m}$ a.s.l., i.e., in the belt of low-mountain relief, and the largest areas affected by ice breaks have northern (about 4000 ha) and northeastern aspects (about $3500 \mathrm{ha}$ ), while the remaining areas evenly belong to other aspects. The slope did not show any significant impact on the occurrence of ice breaks. This 
natural disaster exerted severe and extensive effects on the coniferous and broadleaved forest ecosystem and the environment of the damaged areas, but it also brought about other long-term effects, such as changes in the soil water regime, erosion, declining atmospheric oxygen levels and reduced carbon accumulated in biomass. Furthermore, the degradation processes which are yet to occur will cause the regressive succession of forest communities and the impoverishment of the soil that will be inhabited by those tree species that represent the initial stages in the ontogenetic development of the forest stand. All of the above point to the important role of habitat in the development of forests, but it is also interesting to see how the habitat itself can contribute to the occurrence and intensity of damage.

\title{
REFERENCES
}

ArcGisResources: http://resources.arcgis.com/

Earth Explorer, U.S. Geological Survey: http://earthexplorer.usgs.gov

SE Srbijašume (2015): Action Plan for the Remediation of Damaged State and Privatelyowned Forests for the period from 2015 to 2018 http://www.srbijasume.rs/pdf/Akcioni\%20plan\%20sanacije\%202015-2018.pdf

Kolić, Borislav (1988): Forest eco-climatology with the basics of atmospheric physics. Scientific Book, Belgrade.

\section{DISASTROUS ICE BREAKS IN EASTERN SERBIA - GIS ANALYSIS OF THEIR RELATIONSHIP WITH OROGRAPHIC CHARACTERISTICS}

\author{
Nenad MARKOVIĆ, Miroslava MARKOVIĆ
}

\section{Summary}

At the end of November/beginning of December 2014, an ice wave hit the whole of eastern Serbia and caused extensive ice and snow breaks in the forest areas managed by SE `Srbijašume` - Forest Estates of Niš, Boljevac, Kruševac, Despotovac and Kučevo. The areas affected were determined by identifying all the affected units of forest division - with the lowest accuracy at the level of forest stands and, where possible by GPS recording in the field in order to ensure greater accuracy. The identified areas were presented in GIS mapping software. The total area affected by ice breaks amounted to 19,419.78 ha. It included 8,301.01 ha of high forests, 8,997.37 ha of coppice forests and 2,121.40 ha of artificially-established stands. Considering the size of the forest area affected by ice breaks on the one hand, and the huge environmental impact of forests on the other hand, this phenomenon may be considered a natural disaster. Having identified the affected forest areas, an analysis of the relationship between orographic characteristics and ice break occurrence was carried out with the use of GIS tools. The following orographic characteristics were studied: the elevation, the terrain aspect and the slope, all obtained from the digital elevation model (DEM) at a resolution of 1 arc-second. Elevation had the greatest influence on the occurrence of ice breaks. The largest area affected (ca.17,000 ha) was in the range from 600 to $900 \mathrm{~m}$ above sea level, i.e. in the belt of low-mountain relief. 
Regarding the aspect of the investigated terrain, the largest areas affected by ice breaks had northern (ca. 4,000 ha) and northeastern aspects (ca. 3,500 ha), while the remaining areas were equally distributed in all other aspects. The slope was not found to have any significant effects on the occurrence of ice breaks. This disaster brought about most severe and extensive consequences in broad-leaved and coniferous ecosystems and the environment in general, with long-term adverse effects such as changing soil water regimes, erosion, declining atmospheric oxygen levels and reduced carbon accumulated in biomass. The largest area affected by ice breaks (about 17000 ha) is located in the belt between 600 and $900 \mathrm{~m}$ a.s.l., i.e., in the belt of low-mountain relief, and the largest areas affected by ice breaks have northern (about 4000 ha) and northeastern aspects (about 3500 ha), while the remaining areas evenly belong to other aspects. The slope did not show any significant impact on the occurrence of ice breaks. This natural disaster exerted severe and extensive effects on the coniferous and broadleaved forest ecosystem and the environment of the damaged areas, but it also brought about other long-term effects, such as changes in the soil water regime, erosion, declining atmospheric oxygen levels and reduced carbon accumulated in biomass. Furthermore, the degradation processes which are yet to occur will cause the regressive succession of forest communities and the impoverishment of the soil that will be inhabited by those tree species that represent the initial stages in the ontogenetic development of the forest stand. All of the above point to the important role of habitat in the development of forests, but it is also interesting to see how the habitat itself can contribute to the occurrence and intensity of damage.

\title{
КАТАСТРОФАЛНИ ЛЕДОЛОМИ У ИСТОЧНОЈ СРБИЈИ - ГИС АНАЛИЗА УСЛОВЉЕНОСТИ ОРОГРАФСКИМ КАРАТЕРИСТИКАМА
}

\author{
Ненад МАРКОВИЋ, Мирослава МАРКОВИЋ
}

\section{Резиме}

Крајем новембра и почетком децембра 2014. године, ледени талас који је захватио целу источну Србију проузроковао је појаву великих ледолома, ледоизвала и снеголома на површинама којима газдује ЈП „Србијашуме“, односно на подручју шумских газдинстава Ниш, Бољевац, Крушевац, Деспотовац, и Кучево. Утврђивање површина захваћених ледоломима и ледоизвалама извршено је дефинисањем свих захваћених јединица просторне поделе шума, најмање тачности на нивоу одсека, а где је то било могуће и прецизније снимањем уз помоћ ГПС апарата. Те површине су картиране у ГИС технологији. Укупна површина државних шума захваћених ледоломима је 19.419,78 ha, од чега на високе шуме отпада 8.301,01 ha, изданачке $8.997,37$ ha и вештачки подигнуте састојине 2.121,40 ha. С обзиром на велику површину шума захваћену ледоломима, као и на њен огроман утицај на животну средину, ова природна непогода може се сматрати катастрофалном. После дефинисања површина захваћени ледоломима, ГИС алатима извршена је анализа условљености појаве ледолома орографским карактеристикама. Од орографских карактеристика анализирана је надморска висина, експозиција и нагиб терена. Детаљне орографксе каракеристике подручја захваћених ледоломима добијене су из дигиталног елевационог модела (DEM) прецизности 1 ARC-second. Највећи утицај на појаву ледолома имала је надморска висина. Највећа површина погођена ледоломима (око 17000 ha) налази се у појасу 600-900 м.н.в. тј у појасу нископланинског рељефа. Што се експозиције тиче, највеће површине погођене ледоломима налазе се на северној (око 4000 ha) и североисточној експозицији (око 3500 ha), док је остатак 
површина равномерно распоређен по осталим експозицијама. Нагиб није показао значајан утуцај на појаву ледолома. Констатоване су озбиљне и тешке последице, које је природна непогода оставила на четинарски и лишћарски шумски екосистем и животну средину, као и дуготрајне последице: промена водног режима у земљишту, интензивирање ерозије, смањење количине кисеоника, смањење количине угљеника акумулираног у биомаси. Највећа површина погођена ледоломима (око 17000 ha) налази се у појасу 600-900 м.н.в. тј у појасу нископланинског рељефа, а највеће површине погођене ледоломима налазе се на северној (око 4000 ha) и североисточној експозицији (око $3500 \mathrm{ha}$ ), док је остатак површина равномерно распоређен по осталим експозицијама. Нагиб није показао значајан утуцај на појаву ледолома. Констатоване су озбиљне и тешке последице, које је природна непогода оставила на четинарски и лишћарски шумски екосистем и животну средину, као и дуготрајне последице: промена водног режима у земљишту, ерозију, смањење количине кисеоника, смањење количине угљеника акумулираног у биомаси. Међутим, деградациони процеси који ће тек наступити узроковаће регресију шумских заједница и осиромашење тла на које ће се населити оне врсте дрвећа које представљају сам почетак у онтогенетском развоју шумске састојине. Из свега наведеног јасно се може закључити улога станишта у развоју шуме, али је и занимљиво како станиште може само по себи утицати на појаву и интензитет штета. 